\title{
SIX SIGMA AND QUALITY COST ANALYSIS IN IMPROVING PROFIT
}

\author{
Felisia \\ Ecconomic Faculty, Parahyangan Catholic University \\ email: felisia.liu@unpar.ac.id
}

\begin{abstract}
Quality is one of the key success factors to achieve competitive advantage. When companies succeeded to improve quality of the service or product given, they will have the possibility to increase their market share and eventually their profit. One of the methods to increase quality is by doing six sigma analysis that focuses on the cause of the problem. The research is done in PT Cemara Agung, one of textile industries in Indonesia. Research method used is descriptive study. Literature study, observations, and interviews has been done in order to search root cause and generate recommendations. The analysis shows that almost fifty percent of the main cause in defect products is happened to the weaving department, which then cause the profit of the company decreased as an impact of the spoilage produced. By doing six sigma analysis and finding recommendations to resolve the problems, the company is expected to be able to reduce the quality cost, increase the quality and eventually increase the profit of the company.
\end{abstract}

Keywords: Defects, Profit, Six Sigma, Spoilage, Quality Cost

\begin{abstract}
ABSTRAK
Kualitas merupakan kunci utama keberhasilan bagi perusahaan untuk mencapai keunggulan kompetitif. Dengan meningkatnya kualitas dari produk atau jasa yang ditawarkan, perusahaan diharapkan dapat bersaing dan meningkatkan pangsa pasar, yang pada akhirnya dapat meningkatkan laba yang diperolehnya. Salah satu metode untuk meningkatkan kualitas dari produk atau jasa adalah dengan melakukan analisis six sigma, dimana analisis six sigma berfokus pada penyebab dari permasalahan. Penelitian dilakukan pada PT Cemara Agung yang bergerak dalam bidang tekstil di Indonesia. Metode peneltiian yang dilakukan adalah studi deskripstif dengan melakukan studi literatur dan observasi untuk menganalisis permasalahan dan menghasilkan rekomendasi bagi perusahaan. Hasil analisis menunjukkan bahwa hampir 50\% penyebab terjadinya produk cacat pada perusahaan adalah pada proses tenun. Produk cacat pada proses tenun ini tidak dapat diperbaiki sehingga perusahaan mengkategorikannya sebagai grade B dan menjualnya dengan harga lebih rendah. Dengan melakukan analisis six sigma dan memberikan rekomendasi perbaikan, perusahaan diharapkan dapat mengurangi biaya kualitas yang terjadi dan kemudian tentunya meningkatkan kualitas dari produknya. Pada akhirnya, laba dari perusahaan juga diharapkan dapat meningkat.
\end{abstract}

Kata kunci: Biaya Kualitas, Kualitas, Laba, Six Sigma, Produk Cacat 


\section{INTRODUCTION}

Companies are expected to be able to increase the quality of their services and products. Quality is one of the key success factors to achieve competitive advantage. Delivering service quality is widely recognized as an essential strategy for success (Matthyssens \& Vandenbempt, 1998). When the quality increase, customer satisfaction is also expected to increase, and so does the market share of the company. It is also expected that eventually the profit of the company will increase as well.

In order to increase quality of their products and services, companies need to search ways, one of them are ways to decrease the cause of defects. ISO 9000 is a general framework for quality and Six Sigma concerns variations in products. Some corporations have made substantial savings as a results of using Six Sigma. (Lindström et al., 2020). The focus of Six Sigma is reducing variability in key product quality characteristics to the level at which failure or defects are extremely unlikely (Montgomery, 2012).

Defects are also related to quality cost. Components of quality cost are prevention cost, appraisal cost, internal failure cost, and external failure cost. Where each of it are connected one to another. When defects occur and can be fixed, companies might have the chance to rework it, then internal failure cost will increase. Sometimes defects cannot be fixed, then companies will take option to sell the products with lower selling price. By finding ways to decrease defects and substantially quality cost, companies will have the opportunity to increase their profits.

PT Cemara Agung is located in West Java, Indonesia. It produces greige and patterned cloth from yarn, through machine fabrication processes. The three main products are spandex, polyester, and cotton. The maximum defect rate that is stated by the company is $3 \%$ from total production.

\section{LITERATURE STUDY}

Six Sigma starts from analyzing practical problem, translates it into a statistical domain, works out a statistical solution and then translates it back into a practical solution (Suresh et al., 2012). It can be used to reduce excessive process variation (Suresh et al., 2012). By reducing excessive variation, the process quality, productivity, and efficiency are improved (Antony et al., 2012). This in turn will results in reduced costs, increased business profitability and revenue growth (Suresh et al., 2012). In other words, Six Sigma creates value for the enterprise and the customers (Antony, 2012).

Quality is one of the key success factors in companies. The increasing importance of quality and the emergence of new methods and tools supporting quality management enhance the interest in quality costs (Biadacz, 2020). Quality cost concept first introduced by Juran in his Quality Control Handbook. He stated quality cost as "the costs which would disappear if no defects were produced" (Juran, 1951). Feigenbaum then expanded the definition and divided the quality cost into cost of control and cost of failure of control (Feigenbaum, 1956). Costs of control are divided into prevention and appraisal cost, while the cost of failure to control are divided into internal failure cost and external failure cost.

In the modern view, a dynamic aspect is considered; many investments in prevention occur only once and avoid failure costs thereafter. Over time, the returns of these investments in prevention accumulate, as the root causes of defects are being eliminated. As a result, ever higher quality can be achieved at ever lower total quality cost resulting in a total cost of quality optimum at zero defects (Sturm et al., 2019). 


\section{RESEARCH METHODOLGY}

The method use for this research is descriptive study. A descriptive study is undertaken in order to ascertain and be able to describe the characteristics of the variables of interest in a situation (Sekaran, 2003). Variables of interest in the research are six sigma analysis, quality cost analysis, and profit.

The research is done in PT Cemara Agung that produces textiles in Indonesia, and the period of the research is 2019 . Analysis is done by collecting data from the company including total yields, defects, and costs related. After data is collected, observations in weaving department and interviews to personnel min weaving department are done to obtain more information regarding to defects occurred in the company. Literature study is then conducted to analyze the problems and generate recommendations for solving problems.

\section{RESULT AND DISCUSSION}

\section{Six Sigma Analysis}

Throughout 2019, the average first time yields (FTY) is 93\% while the average Defects Per Million Opportunities (DPMO) is 87,512 as shown in table 1 .

Table 1. Yields and DPMO

\begin{tabular}{|c|c|c|c|c|c|c|}
\hline Products & Grade A (yards) & Defects (yards) & $\begin{array}{l}\text { Total production } \\
\text { (yards) }\end{array}$ & defects $\%$ & yields & Avera \\
\hline Spandex & $485.821,40$ & $24.629,56$ & $510.450,96$ & $4,83 \%$ & $95,17 \%$ & \\
\hline Polyester & $1.968 .411,00$ & $276.306,00$ & $2.244 .717,00$ & $12,31 \%$ & $87,69 \%$ & \\
\hline Cotton & $4.159 .708,00$ & $166.408,50$ & $4.326 .116,50$ & $3,85 \%$ & $96,15 \%$ & \\
\hline
\end{tabular}

Source: Processed Primary Data

These number may still have ambiguous interpretation whether the company has performed well or not, so we need to reassure it by calculating the sigma score using Microsoft Excel formula. The average six sigma score for the company is 3,1 $\sigma$ which indicate that the production process has not been merely effective, because the optimal score for six sigma is supposed to be around $6 \sigma$.
Table 2. Six Sigma Score

\begin{tabular}{|l|l|c|l|}
\hline Products & weighting & $\begin{array}{l}\text { total } \\
\text { production } \\
\text { (yards) }\end{array}$ & $\begin{array}{l}\text { weighted six } \\
\text { sigma score }\end{array}$ \\
\hline Spandex & $7.21 \%$ & $510.450,96$ & $3.28 \sigma$ \\
\hline Polyester & $31.70 \%$ & $2.244 .717,00$ & $2.70 \sigma$ \\
\hline Cotton & $61.09 \%$ & $4.326 .116,50$ & $3.34 \sigma$ \\
\hline
\end{tabular}

Source: Processed Primary Data

The next step is to search the cause of defects that occurs in the company. There are 10 types of defects identified. From the pareto diagram analysis, it can be seen that LG (Lusi Garis), PCP (Pakan Campur), BAR (Benang Putus Arah Lebar), OIL (Oli), and BL (Belang) are most defects that happened and contribute almost $85 \%$ from total defects occurred. LG, PCP, and BAR occurs in weaving process. While OIL and BL occurs in dyeing department.

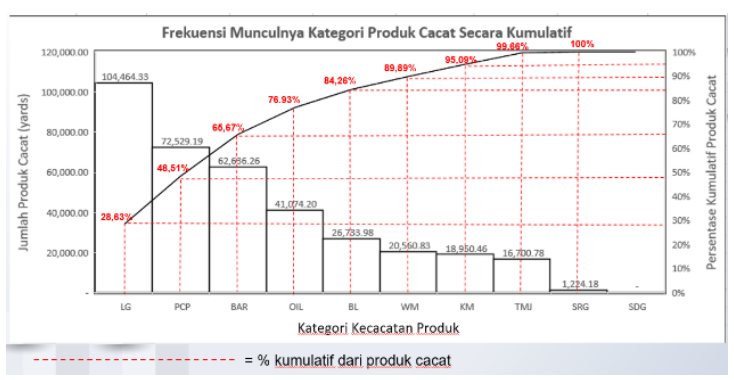

Source: Processed Primary Data

Figure 1. Pareto Diagram

Defects that occurred do to dyeing department tend to be fixed. It can be re dye to fix it. The company need to spend on chemical materials, labor and electricity to do the rework, but the products then can be sold at normal selling price that is Rp.25.000 per yard. So, the company does need to spend more but the loss is not material.

In the other hand, the defects in weaving process cannot be fixed. The company then must sell the products that resulting in lower selling price (Grade B products). Defects that occur from weaving department totaling 354.158 yards cannot be fixed and then sold at as Grade B products for Rp.12.000 per yard. 
Due to this spoilage, the company suffers opportunity loss around eleven billion rupiah during 2019.

Recommendations to cope with this problem are buying new weaving machine, conduct employee training, and scheduling routine maintenance. Buying new weaving machine sounds quite expensive and tend to make us wonder, do we really need it. Through observations done, the information obtained is that the weaving machines existed now do not have features to pause the weaving process automatically when there are yarns are broken nor when dropper parts fell out from the machine. Besides that, some of the weaving machines existed have parts that are broken especially in waterjet part. This part is somehow quite hard to be fixed. These are the main cause of LG, PCP and BAR type of defects. So, buying new weaving machine hopefully can overcome these defects.

Besides buying new types of weaving machines, the capabilities of the labor that operates the machines need to be adjusted to. If they are not capable in operating it, then buying the machines will be useless. That is why, employee training needs to be done too. And the company is recommended to do routine maintenance for the new machine in order to avoid breakdowns.

\section{Quality Cost Analysis}

As mentioned earlier, the company suffered opportunity loss around eleven billion rupiah in 2019, to overcome this prevention actions recommended is to buy new types of weaving machines, conduct employee training, and schedule routine maintenance. Below is the estimated prevention cost that might occur from the recommendations.
Table 3. Estimated total cost from implementing recommendations

\begin{tabular}{|l|c|}
\hline \multicolumn{2}{|c|}{ New Weaving Machines } \\
\hline Estimated cost per machine & $\mathrm{Rp}$ \\
\hline Quantity & 141.210 .000 \\
\hline $\begin{array}{l}\text { Estimated total cost from buying new } \\
\text { machines }\end{array}$ & Rp4.236.300.000 \\
\hline \multicolumn{2}{|c|}{} \\
\hline Estimated trainer salary per month & $\mathrm{Rp}$ \\
\hline Estimated working hours per month (trainer) & 7.500 .000 \\
\hline Estimated trainer cost per hour (salary) & $\mathrm{Rp}$ \\
\hline Estimated no of employee trained & 173 \\
\hline Estimated training hours per employee & 10 \\
\hline Estimated no of training per year & 5 \\
\hline $\begin{array}{l}\text { Estimated total cost from training } \\
\text { employees }\end{array}$ & $\mathbf{R p}$ \\
\hline \multicolumn{2}{|c|}{$\mathbf{8 . 6 7 0 . 5 2 0}$} \\
\hline Estimated techinician cost per machine & $\mathrm{Rp}$ \\
\hline No of machines & \multicolumn{2}{|c|}{300.000} \\
\hline Estimated no of maintenance per year & $\mathbf{R p}$ \\
\hline $\begin{array}{l}\text { Estimated total cost from routine } \\
\text { maintenace }\end{array}$ & $\mathbf{1 0 8 . 0 0 0 . 0 0 0}$ \\
\hline
\end{tabular}

Source: Processed Primary Data

Next step is to do what if analysis to calculate estimated profit per year.

Table 4. Estimated Profit What-if Analysis

\begin{tabular}{|l|r|r|r|r|r|}
\hline $\begin{array}{c}\text { Estimated } \\
\text { reductions } \\
\text { in defects }\end{array}$ & $\begin{array}{c}\text { Estimated no of } \\
\text { defects after } \\
\text { implementing } \\
\text { reccomendations } \\
\text { (yard) }\end{array}$ & $\begin{array}{c}\text { Estimated } \\
\text { rework cost } \\
\text { after defects in in } \\
\text { weaving } \\
\text { department } \\
\text { reduced (Rp.) }\end{array}$ & $\begin{array}{c}\text { Estimated profit } \\
\text { earned from } \\
\text { selling Grade B } \\
\text { products (Rp.) }\end{array}$ & $\begin{array}{c}\text { Estimasi laba } \\
\text { setelah } \\
\text { melakukan } \\
\text { indakan } \\
\text { perbaikan }\end{array}$ & $\begin{array}{c}\text { Estimated profit } \\
\text { after implementing } \\
\text { reccomendations } \\
\text { (Rp.) }\end{array}$ \\
\hline $100 \%$ & - & 828.249 .874 & & $12,749,680,400$ & 11.921 .428 .982 \\
\hline $90 \%$ & 84.998 & 828.249 .874 & 169.995 .840 & $11,474,712,360$ & 10.816 .456 .680 \\
\hline $80 \%$ & 169.996 & 828.249 .874 & 339.991 .680 & $10,199,744,320$ & 9.711 .484 .379 \\
\hline $70 \%$ & 254.994 & 828.249 .874 & 509.987 .520 & $8,924,776,280$ & 8.606 .512 .078 \\
\hline $60 \%$ & 339.992 & 828.249 .874 & 679.983 .360 & $7,649,808,240$ & 7.501 .539 .776 \\
\hline $50 \%$ & 424.990 & 828.249 .874 & 849.979 .200 & $6,374,840,200$ & 6.396 .567 .475 \\
\hline $40 \%$ & 509.988 & 828.249 .874 & 1.019 .975 .040 & $5,099,872,160$ & 5.291 .595 .174 \\
\hline $30 \%$ & 594.985 & 828.249 .874 & 1.189 .970 .880 & $3,824,904,120$ & 4.186 .622 .872 \\
\hline $20 \%$ & 679.983 & 828.249 .874 & 1.359 .966 .720 & $2,549,936,080$ & 3.081 .650 .571 \\
\hline $10 \%$ & 764.981 & 828.249 .874 & 1.529 .962 .560 & $1,274,968,040$ & 1.976 .678 .270 \\
\hline
\end{tabular}

Source: Processed Primary Data

Interpolation is done to calculate estimated number of defects occurred after implementing recommendations. The result is:

$$
Y=40 \%+\left[\frac{(4.236 .300 .000-4.186 .622 .872)}{(5.291 .595 .174-4.186 .622 .872)}(40 \%-30 \%)\right]=31 \%
$$

The company needs to be sure that the recommendations applied are able to decrease the defects cause by weaving process for $31 \%$, in order to cover the investment from buying the new machines in the same year.

The next table shows estimated quality cost before and after implementing 
recommendations for the first year of operation.

Table 5. Estimated Quality Cost

\begin{tabular}{|c|c|c|c|c|}
\hline & \multicolumn{4}{|c|}{ First year } \\
\hline & & Before & & After \\
\hline \multicolumn{5}{|l|}{ Prevention cost } \\
\hline New machine maintenance & $\mathrm{Rp}$ & - & & 108.000 .000 \\
\hline Employee training & $\mathrm{Rp}$ & - & $\mathrm{R}$ & 8.670 .520 \\
\hline New machine depreciation & $\mathrm{Rp}$ & - & $\mathrm{R}$ & 264.768 .750 \\
\hline \multicolumn{5}{|l|}{ Extenal Failure Cost } \\
\hline $\begin{array}{l}\text { Opportunity loss from } \\
\text { selling grade B products }\end{array}$ & & 11.049 .729 .600 & & 7.624 .313 .424 \\
\hline Total & & 11.049 .729 .600 & & 8.005 .752 .694 \\
\hline
\end{tabular}

Source: Processed Primary Data

From the table above, the company is estimated to incur more prevention cost for the first year of operation. These prevention cost incur due to maintenance cost, employee training cost, and new machine depreciation cost. As for the external failure cost, company will be able to save around 3 billion rupiah from opportunity cost due to selling grade B products, because the defects will be decreased.

The analysis done only considers relevant cost incurred. The analysis also has not considered whether the company should sell the old machine or keep it. The company needed more considerations in making decisions whether to sell the old machines or not, like whether the manufacturing capacity is enough or not, the layout, and if the company decided to not sell it will there be more workers needed to operate it or not. These considerations need to be evaluated more and not is not discussed in this paper.

\section{CONCLUSION AND LIMITATION}

The sigma score of the company is $3.1 \sigma$, this indicates that the production is still not effective. Defects that most occurred are LG (Lusi Garis), PCP (Pakan Campur), BAR (Benang Putus Arah Lebar), OIL (Oli), and BL (Belang). Where LG, BAR, and PCP are occurred in weaving process. This paper analyzed the cause and recommended actions to improve the quality that is by buying new types of weaving machines, doing employee training, and scheduling routine maintenance.

These recommendations are generated after doing observations before. It is indicated that the weaving machines now existed in the company do not have features to pause the weaving process automatically when there are yarns are broken nor when dropper parts fell out from the machine. Besides that, some of the weaving machines existed have parts that are broken especially in waterjet part. This part is somehow quite hard to be fixed.

It is expected that the company will be able to reduce its defects in weaving process and decrease the quality cost by 3 billion rupiah after implementing the recommendations in the first year. With the improvement in quality and decrease in quality cost, it is also expected that the company will be able to gain more market share and eventually increase their profits.

The research also has limitations which are the area analyzed is only in the weaving department that contributes $50 \%$ of defects occurred, there has not been any considerations about whether to sell the old machines or not. Besides that, recommendation to buy new type of machines also need further analysis related to the company's cash flow.

\section{ACKNOWLEDGMENT}

I would like to thank Arthur Purboyo, Drs., MPAc., Ak and Joshua Michael Selano for providing data and for their valuable contribution in finding recommendations.

\section{REFERENCES}

Antony, J. (2012). A SWOT analysis on Six Sigma: Some perspectives from leading academics and practitioners. International Journal of Productivity and Performance Management, 61(6), 691-698. https://doi.org/10.1108/17410401211 249229 
Antony, J., Bhuller, A. S., Kumar, M., Mendibil, K., \& Montgomery, D. C. (2012). Application of Six Sigma DMAIC methodology in a transactional environment. International Journal of Quality and Reliability Management, 29(1), 3153. https://doi.org/10.1108/02656711211 190864

Biadacz, R. (2020). Quality cost management in the SMEs of Poland. TQM Journal. https://doi.org/10.1108/TQM-092019-0223

Feigenbaum, A. . (1956). Total quality control. Harvard Business Review, 34(6), 93-101.

Juran, J. M. (1951). Quality Control Handbook (1st ed.). McGraw-Hill, New York, NY.

Lindström, J., Kyösti, P., Birk, W., \& Lejon, E. (2020). An initial model for zero defect manufacturing. Applied Sciences (Switzerland), 10(13), 1-16. https://doi.org/10.3390/app10134570

Matthyssens, P., \& Vandenbempt, K. (1998). Creating competitive advantage in industrial services. Journal of Business and Industrial Marketing, 13(5), 339-355. https://doi.org/10.1108/08858629810 226654

Montgomery, D. C. (2012). Introduction to Statistical Quality Control (seventh, Vol. 66). John Wiley \& Sons, Inc.

Sekaran, U. (2003). Research Methodds For Business Fourth Edition. For Business Fourth Edition.

Sturm, S., Kaiser, G., \& Hartmann, E. (2019). Long-run dynamics between cost of quality and quality performance. International Journal of Quality and Reliability Management, 36(8), $1438-1453$. https://doi.org/10.1108/IJQRM-052018-0118

Suresh, S., Antony, J., Kumar, M., \& Douglas, A. (2012). Six Sigma and leadership: Some observations and agenda for future research. TQM

Journal, 24(3), 231-247.

https://doi.org/10.1108/17542731211

226754 